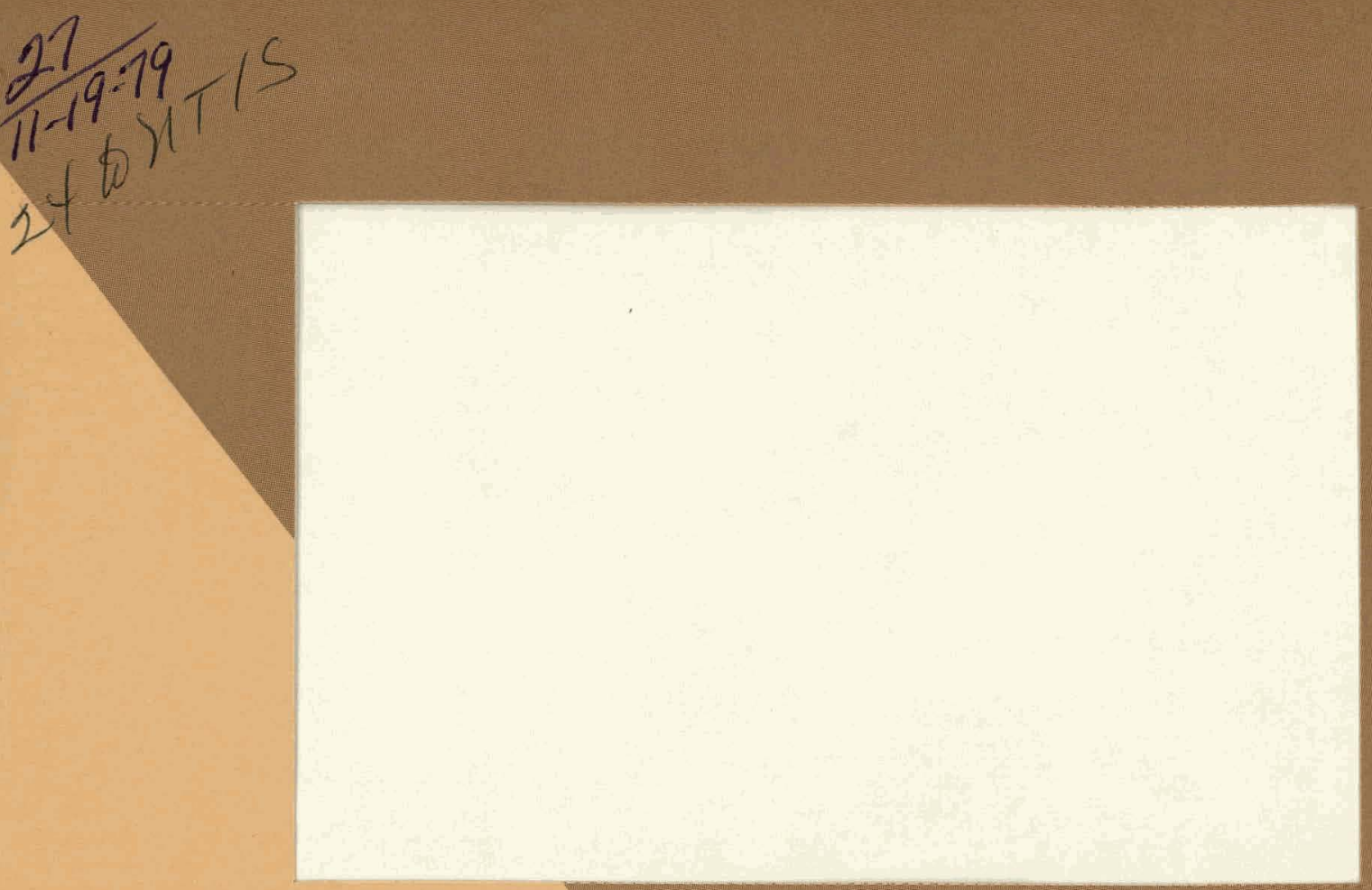

\title{
InTEGRATEd
}

Assessments

And

\section{Policy Evaluations}




\section{DISCLAIMER}

This report was prepared as an account of work sponsored by an agency of the United States Government. Neither the United States Government nor any agency Thereof, nor any of their employees, makes any warranty, express or implied, or assumes any legal liability or responsibility for the accuracy, completeness, or usefulness of any information, apparatus, product, or process disclosed, or represents that its use would not infringe privately owned rights. Reference herein to any specific commercial product, process, or service by trade name, trademark, manufacturer, or otherwise does not necessarily constitute or imply its endorsement, recommendation, or favoring by the United States Government or any agency thereof. The views and opinions of authors expressed herein do not necessarily state or reflect those of the United States Government or any agency thereof. 


\section{DISCLAIMER}

Portions of this document may be illegible in electronic image products. Images are produced from the best available original document. 
The facilities of Argonne National Laboratory are owned by the United States Government. Under the terms of a contract (W-31-109-Eng-38) among the U. S. Department of Energy, Argonne Universities Association and The University of Chicago, the University employs the staff and operates the Laboratory in accordance with policies and programs formulated, approved and reviewed by the Association.

\section{MEMBERS OF ARGONNE UNIVERSITIES ASSOCIATION}

The University of Arizona Carnegie-Mellon University Case Western Reserve University The University of Chicago University of Cincinnati IIlinois Institute of Technology University of Illinois Indiana University The University of lowa lowa State University
The University of Kansas

Kansas State University

Loyola University of Chicago

Marquette University

The University of Michigan

Michigan State University

University of Minnesota

University of Missouri

Northwestern University

University of Notre Dame
The Ohio State University Ohio University

The Pennsylvania State University

Purdue University

Saint Louis University

Southern Illinois University

The University of Texas at Austin Washington University

Wayne State University

The University of Wisconsin-Madison

\section{NOTICE}

This report was prepared as an account of work sponsored by the United States Government. Neither the United States nor the United States Department of Energy, nor any of their employees, nor any of their contractors, subcontractors, or their employees, makes any warranty, express or implied, or assumes any legal liability or responsibility for the accuracy, completeness or usefulness of any information, apparatus, product or process disclosed, or represents that its use would not infringe privately-owned rights. Mention of commercial products, their manufacturers, or their suppliers in this publication does not imply or connote approval or disapproval of the product by Argonne National Laboratory or the U. S. Department of Energy.

Technical memoranda (ANL/EES-TM series) produced by the Integrated Assessments and Policy Evaluations group of Argonne's Energy and Environmental Systems Division are informal reports which present preliminary portions of work in progress, or work that is more limited in scope than that discussed in formal analysis and assessment reports (ANL/AA series). 
ANL/EES-TM-68

A REVIEW OF THE NUCLEAR

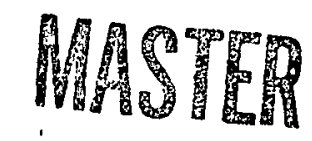
WASTE DISPOSAL PROBLEM

OCTOBER 1979

\author{
BY L.A. POCH \\ T.D. WOLSKO
}

PREPARED BY:

INTEGRATED ASSESSMENTS AND POLICY EVALUATIONS GROUP

ENERGY. AND ENVIRONMENTAL SYSTEMS DIVISION

ARGONNE NATIONAL LABORATORY

ARGONNE, ILLINOIS 604.39

PREPARED FOR:

This book was prepared as an account of work sponsored by an agency of the Unired States Government. Neirther the United States Government nor any agency thereoft, nor any of their emplovees, makes any wastranty, express or implied, or assumes eny legal liability or responsibility for the accuracy. completeness, or usefulness of any information, apparatus. product, or process disclosed. or represents that its use would not infringe privitely owned rights. Rejerenece herein to any specific not necessarily constitute or imply its endorsement, recommendation. or fovoring by the United States Government or any gencer thereot. The views and opinions of authors expressed herein do not
necessarily state or reflect those of the United States Government or any agency theseor.

SATELITE POWER SYSTEM PROUECT OFFICE OFFICE OF ENERGY RESEARCH

U.S, DEPARTMENT OF ENERGY 
THIS PAGE

\section{WAS INTENTIONALLY \\ LEFT BLANK}


1 INTRODUCTION . . . . . . . . . . . . . . . . . . . . 1

2 NATURE OF RADIOACTIVE WASTES . . . . . . . . . . . . . . . . 2

2.1 Introduction. . . . . . . . . . . . . . . . . . . 2

2.2 Classes of Nuclear Wastes . . . . . . . . . . . . . . 2

2.2.1 High-Level Wastes. . . . . . . . . . . . . . 2

2.2.2 Transuranic Wastes . . . . . . . . . . . . . . . 4

2.2.3 Low-Level Wastes... . . . . . . . . . . . . . . 4

2.2.4 Uranium Tailings... . . . . . . . . . . . . . . . . . 4

2.2.5 Decommissioning/Decontamination Wastes . . . . . . . . 5

3 WASTE DISPOSAL TEChNOLOGIES . . . . . . . . . . . . . . . . . . 6

3.1 Introduction. : . . . . . . . . . . . . . . . . . 6

3.2 Burial in Deep Geological Formations. . . . . . . . . . . . . 6

3.3 Seabed Disposal . . . . . . . . . . . . . . . . . . 7

3.4 Ice Sheet Disposal. . . . . . . . . . . . . . . . . . 7

3.5 Extraterrestrial Disposal . . . . . . . . . . . . . 8

3.6 Transmutation . . . . . . . . . . . . . . . . . 8

3.7 Disposal by Rock Melting in Deep Mined Cavities . . . . . . . . . 9

3.8 Disposal in Deep Drilled Holes. . . . . . . . . . . . . . . . 9

4 RISKS OF RADIOACTIVE WASTE DISPOSAL. . . . . . . . . . . . . . . . 10

4.1 Introduction. . . . . . . . . . . . . . . . . . . . 10

4.2 Risks of High-Level Waste Disposal. . . . . . . . . . . . . 10

4.3 Risks of Transuranic Waste Disposal . . . . . . . . . . . . . . 13

4.4 Risks of Low-Level Waste Disposal . . . . . . . . . . . . . . . . 13

4.5 Risks of Uranium Tailings Disposal. . . . . . . . . . . . . . . 14

4.6 Risks of Decontamination/Decommissioning Waste Disposal . . . . . 14

5 CONCLUSIONS. . . . . . . . . . . . . . . . . . . . . 15

6 REFERENCES ............................. . . . 16 


\section{THIS PAGE \\ WAS INTENTIONALLY \\ LEFT BLANK}




\section{INTRODUCTION}

Dealing with the problems posed by nuclear waste management is a major issue confronting continued use of the nuclear fuel cycle. Large amounts of radioactive wastes have already been generated as a result of past nuclear reactor operations, but these wastes are being temporarily kept in aboveground storage facilities awaiting a government policy decision on final disposition. Although research on various technologies to dispose of radioactive wastes is given high priority, a commercial waste disposal facility is not expected to be in operation before 1985. The magnitude of the waste disposal problem and the waste management techniques themselves are directly affected by the nuclear fuel cycle used. Whether the once-through, lightwater reactor (LWR) cycle or the fast-breeder reactor (FBR) will be used in the future will determine the types of wastes to be disposed of and thus dictate the technology(ies) to be used to dispose of them. Even if no new reactors are built, nuclear wastes would continue to be generated for another 30 years by the reactors in operation today. Hence, there is no easy solution to the nuclear waste management problem.

The type of risk we are willing to live with is the main issue that must be addressed in nuclear waste management. Theoretically, all waste disposal technologies under consideration will provide long-term isolation of such wastes from the biosphere; however, some require spent fuel to be reprocessed, which increases the proliferation risk, while others rely upon theories that have not yet been rigorously tested. Although continued research will answer some questions, other questions may never be adequately resolved.

This paper surveys the current situation regarding radioactive waste management and disposal methods and assesses, as well the risks associated with the waste disposal technologies. The origin of radioactive wastes is discussed first to approximate the kinds and quantities of wastes that are generated. Then various waste disposal technologies are examined along with their possible advantages, disadvantages, and projected costs. Finally, several areas of potential risk are identified and each of the technologies are compared in terms of their ability to deal with a particular risk. 


\section{NATURE OF RADIOACTIVE WASTES}

\subsection{INTRODUCTION}

Radioactive wastes, the inevitable by-products of the generation of electricity by nuclear reactors, are encountered at all stages of the nuclear fuel cycle -- in mining and milling, in fuel fabrication, in reactor operation, in spent fuel assemblies, and in the reprocessing of spent fuel, should it become a reality for future generations. Figure 1 shows a block diagram of the types of radioactive wastes generated in each phase of the uranium-based fuel cycle, with and without fuel recycling or reprocessing. Fuel cycles utilizing other nuclear fuels (e.g., thorium or mixtures of thorium and uranium) have similar flow charts. As shown in Figure 1, each phase of the fuel cycle produces one or more types of radioactive waste. By far, however, the lasgest quanticles of radioactivity are produced by the nuclear processes that generate power in the reactor, i.e., spent fuel, which is removed annually from the reactor and not reprocessed, or high-level wastes resulting from spent fuel reprocessing. The final disposition of both of these radioactive wastes has been a major obstacle to the worldwide expansion of nuclear power.

\subsection{CLASSES OF NUCLEAR WASTES}

There are five classes of nuclear wastes ${ }^{1}$ : high-level waste (HLW), made up of spent fuel and reprocessing wastes; transuranic (TRU) waste; low-level waste (LLW); uranium tailings; and decommissioning/decontamination (D/D) waste. Because each type of waste varies in radioactivity, toxicity, and heat generation, different waste management techniques and specifications are needed in order to assure isolation of each waste type from the biosphere.

\section{2 .1 High-Level Hastes (IlLWs)}

High-level wastes can be either intact spent fuel assemblies removed from a reactor after serving their useful life or the wastes generated as a result of spent fuel reprocessing. A 1000-MWe 1 ight-water reactor discharges annually about 30 metric tons $(t)$ of spent fuel using the present once-through fuel cycle $e^{2}$. Because of the density of the spent fuel, this quantity anly occupies about $2 \mathrm{~m}^{3}$ of space. ${ }^{3}$ Commercial spent fuel contains about 96 weight \% of the uranium originally charged to the reactor as fresh fuel in addition to 3 weight \% fission products and 1 weight \% TRU elements and daughters. 4 Most fission products decay to stable elements after several hundred years, whereas TRU elements remain radioactive for thousands of years. Consequently, spent fuel initially generates a great deal of heat and is very radioactive. After a decade, the heat generated decays by a factor in excess of 300 , while the radioactivity derays by a factor of $1000 .{ }^{2}$ Currently, commercial spent fuel assemblies are stored at the reactor site awaiting a decision on the question of spent fuel reprocessing. If reprocessing is not used in the nuclear fuel cycle, spent fuel will remain the bulk of the waste generated. Twenty-three hundred metric tons of heavy metal already exist from past reactor operations. ${ }^{1}$, 


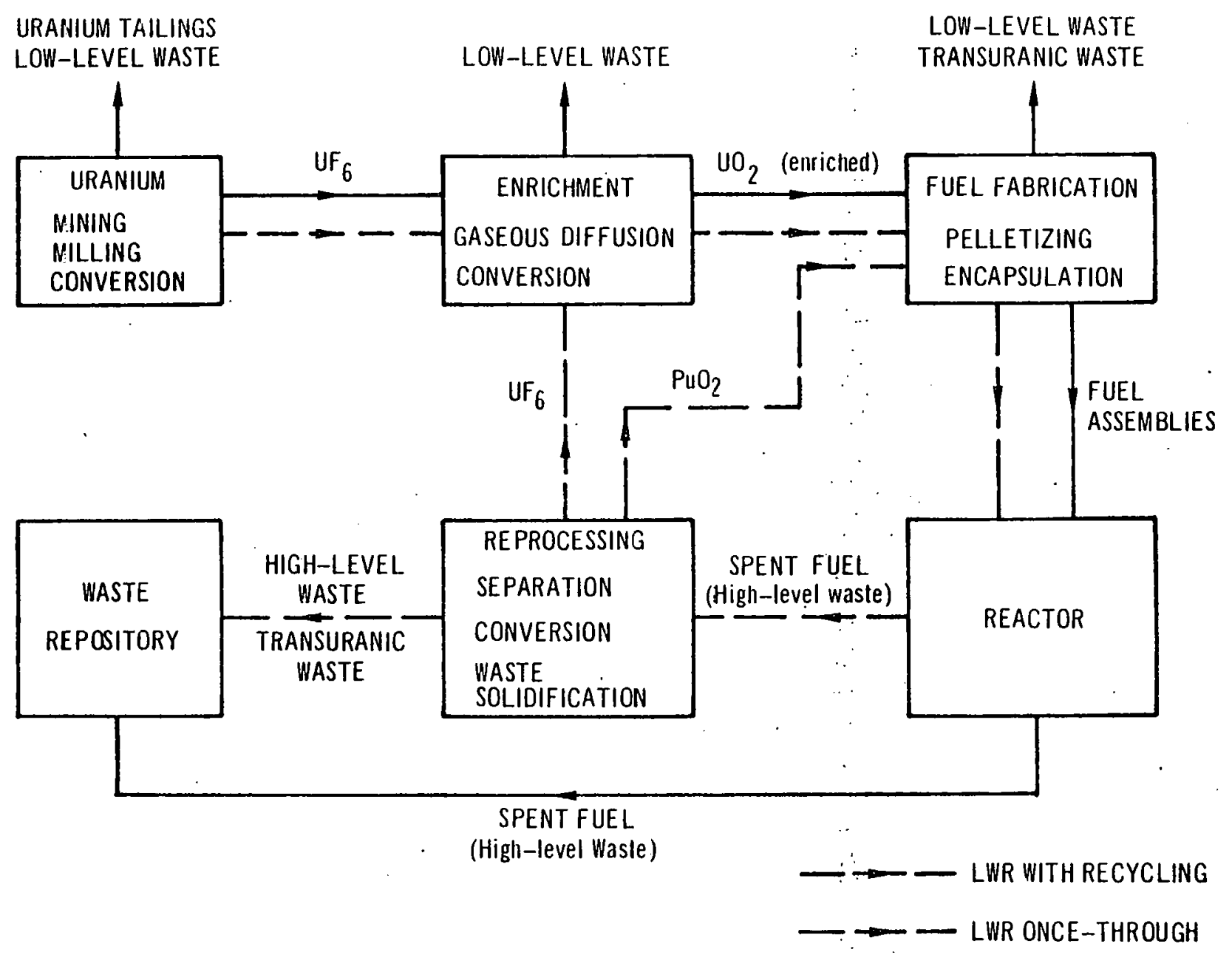

Fig. 1. Block Diagram of LWR Fuel Cycle with and without Fuel Recycling/Reprocessing (adapted from Ref. 6) 
If the nuclear fuel cycle is closed and spent reactor fuel is reprocessed to recover uranium and/or plutonium, a different type of HLW will become the bulk of the wastes generated. Reprocessing wastes contain 84 weight $\%$ fission products and 16 weight $\%$ actinide wastes, 5 i.e., elements with atomic numbers greater than the element actinium. In addition to lessening the volume of wastes that must be disposed of, spent fuel reprocessing reduces the amounts of transuranic elements in the waste. However, the consequent reduction in waste disposal risk achieved by reprocessing and recycling must be balanced against the new risks entailed in using plutonium in the active fuel cycle and in processing large quantities of radioactive materials. Reprocessing wastes to be disposed of now constitute 2,200 of commercial and $260,000 \mathrm{~m}^{3}$ defense material. 1 The total volume of this waste would be enough to fill a two-story building covering an area of one square city block.

\subsubsection{Transuranic (TRU) Wastes}

Transuranic wastes, i.e., wastes containing elements with atomic numbers greater than uranium, result primarily from spent fuel reprocessing and fuel assembly refabrication; very little is generated by the once-through fuel cycle. Transuranic wastes are currently defined as material conntaining more than 10 nanocuries of TRU activity per gram of material.6 Because of their long half-lives, TRU wastes must be isolated from the biosphere for time periods similar to those for HLWs, i.e., $10^{3}$ to $10^{6}$ years. 7 However, problems associated with heat generation and temperature increases are absent, and since TRU wastes are easier to handle than HLWs, the operational demands on a disposal system designed for TRU waste alone would be more modest than those associated with an HLW repository. This means a sperial TRI repository could precede the development of an HLW repository due to the elimination of concerns about heating effects. From past reprocessing operations, $123 \mathrm{~kg}$ of commercial and $1100 \mathrm{~kg}$ of defense TRU wastes need to be disposed of. 1

\section{2 .3 Low-Level Wastes (LLWs)}

In contrast to TRU wastes, LLWs are defined as containing less than 10 nanocuries of TRU per gram of material or may be altogeter free of TRU activity, but LLWs might have potentially hazardous amounts of fission products. LLWs are generated in all phases of the nuclear fuel cycle and nther operations that utilize radioisotopes. Disposal of LLWs consists of burial in shallow pits; $14 \times 10^{6}$ of commercial and $46 \times 10^{6} t$ of defense LLWs have already been buried. 1

\subsubsection{Uranium Tailings}

The residues from the mining and milling of uranium also contain low concentrations of naturally occurring radioactive elements. Uranium mill tailings are generated in large volumes and $130 \times 10^{6} \mathrm{t}$ now are stored uncovered at various sites of mining and milling operations. 1 Because tailings emit the carcinogenic gas radon-222, the stabilization of these piles from water and erosion is of great concern. According to Victor Gilinsky, nuclear physicist and NRC member, uranium tailings could become the dominant 
source of radiation exposure to the public from the nuclear fuel cycle, unless the tailings are isolated from the atmosphere. 8

\subsubsection{Decommissioning/Decontamination (D/D) Wastes}

The final category of nuclear wastes involves those generated upon the retirement of a nuclear facility due to obsolescence or adverse economics of continued operation. $D / D$ is potentially a source of large quantities of radioactive wastes. The volume of LLW (no TRU) that might result after the shutdown of an 1160 MWe reactor could vary from $60 \mathrm{~m}^{3}$ under a mothballing procedure, to $23,000 \mathrm{~m}^{3}$ for complete removal/dismantling. ${ }^{4}$ Until retired nuclear facilities and land are decontaminated, such facilities and land must be considered and treated as waste storage sites. 


\section{WASTE DISPOSAL TECHNOLOGIES}

\subsection{INTRODUCTION}

Many techniques for the disposal of radioactive wastes are under investigation. They include deep geological burial; seabed, ice sheet, and extraterrestrial disposal; transmutation; and disposal by rock melting in deep mined cavities, and in deep drilled holes. Some of these technologies are suitable for one or several types of radioactive waste. However, because some important decisions concerning nuclear energy, namely, spent fuel reprocessing and use of the breeder reactor, have been deferred indefinitely, work is continuing on methods to dispose of all kinds of wastes. Furthermore, many methods need to be reseached and developed as a hedge against any of them proving to be technically impossible or environmentally undesirable. Consequently, the remainder of this chapter briefly explains each of the abovementioned disposal rechniques and relates its advantages, disadvantages, and associated costs.

\subsection{BURIAL IN DEEP GEOLOGICAL FORMATIONS}

Burial of radioactive wastes in deep geological formations or repositories is the most advocated technique. Of all the candidate rock formations under consideration, i.e., anhydrite (calcium sulfate), granite, shale, flood basalt, tuffs, and unsaturated rocks, rock salt is the most studied and foremost candidate. Rock salt has the favorable characteristics of high thermal conductivity, high structural strength, and plastic flow under pressure. In addition, salt is abundant throughout the United States and salt mining is highly developed. Extensive testing of rock salt as a repository medium was made in an abandoned salt mine near Lyons, Kansas, from 1965-1967. Then in 1970 when the AEC announced plans to construct a full-scale pj.1nt. disposal plant on this site, public pressure as well as some unforesen technical difficulties forced abandonment of the project. Hence, the DOE is planning to construct a new salt repository near Carlsbad, N.M., for disposal of TRU military waste and for experimentation with other types of waste.9 The project, called the Waste Isolation Pilot Plant (WIPP) is scheduled to begin operation in 1985. The costs associated with waste burial in geologic repositories, the least expensive of any waste disposal technology, are approximately $\$ 50 / \mathrm{kg}$ of spent fuel. 6

Waste form is an important consideration in the suceess of geologic burial. Because of the corrosive nature of groundwater, any container the wastes are phaced in will lose its integrity after about 100 years, leaving the wastes themselves subject to the leaching action of groundwater. Consequently, the wastes must be cast into forms of extremely low solubility and resistent to the effects of radiation. Liquid wastes must first be solidified and then fixed into a borosilicate glass, ceramic, oxide, or silicate mineral form. Wastes such as contaminated trash (e.g., paper and gloves) will probably be incinerated and the ashes fixed into an inert form such as glass, concrete, metal, or synthetic mineral. Spent fuel rods are in a ceramic form already and will merely be placed in stainless-steel cannisters for burial. 
Before proceeding with large-scale disposal of radioactive wastes in geologic repositories, several issues still need to be resolved. First, the scientific community is not totally convinced that geologic burial is completely safe because accurately predicting the fate of buried radionuclides over several hundred to millions of years is unprecedented and challenging. 6 Because the earth science disciplines are relatively new, there is little experience with the long-term effects of heat on rock mechanics, groundwater on the leaching and transport of wastes, and tectonic history on the host medium. Second, test facilities are needed in order to fill the aforementioned knowledge gaps. Third, criteria for repository site locations must be established so that major population centers and minable resources can be sufficiently isolated from waste repositories. It is hoped that the DOE's WIPP wi 11 be a step in this direction.

\subsection{SEABED DISPOSAL}

Disposal of radioactive wastes at sea involves either implanting waste cannisters on the ocean floor by means of a free-fall penetrometer (an aerodynamically stable body with a pointed nose and stabilizing fins) or using remotely operated machinery on the ocean floor to drill the holes, emplace the waste cannisters, and later backfil1.6 The advantages to this waste disposal technology are its remoteness from society, high isolation from the biosphere, high heat sink capability, and a large available area. Furthermore, the problem of gaining access and control of terrestrial sites is avoided by using the ocean as a burial site.

The disadvantages involved with seabed disposal include the difficulties in guaranteeing the integrity of the waste container given the corrosiveness of sea water, in monitoring and retrieving the waste cannisters, and in the extra ocean transportation and port facilities required. Finally, the issue of the political ramifications of the so-called London Convention must be addressed. This treaty addresses the issue of defining high-level radioactive matter unsuitable for dumping at sea and indicates that wastes should be emplaced only if they have a relatively low radioactive leve1.10 Further research is needed to resolve the aforementioned uncertainties in seabed disposal as well as to place a cost estimate on the various candidate wastes.

\subsection{ICE SHEET DISPOSAL}

Burial of radioactive wastes in the Antarctic ice is also being considered. The waste canisters could be placed on the ice and allowed to sink vertically into the polar ice cap due to the heat generated by radioactive decay of the waste. As the container sinks, the water behind it refreezes, thereby sealing the opening. Additional advantages include a low temperature for cooling, high isolation from society, and the possibility of using the Antarctic an an international waste disposal site.

However, many questions concerning ice sheet disposal need to be researched. They include the problem of long-term stability of the ice sheets, the lack of detailed knowledge of the thermal, chemical, physical, and mechanical properties of ice sheets, and the unknown thermal and radiological effects on perma frost. Another factor is that once the waste canisters have 
melted their way into the ice sheet, retrieval of the containers is very difficult to say nothing of the forbidding climate in which to work. Lastly, in accordance with the Antarctic Treaty of 1959 disposal of radioactive waste in the Antarctic ice sheets is forbidden.

\subsection{EXTRATERRESTRIAL DISPOSAL}

Ejection of radioactive wastes into space is another waste disposal concept being researched. Various space disposal options have been considered, including earth, moon, or solar orbit, escape from the solar system, or impact with the sun. All of the above options are possible except the solar impact option, which is beyond the capability of present chemical propulsion systems.11 The advantages of extraterrestrial disposal include the distance from society, the impossibility of the accidental return of the waste once it is in space, and the possibility of taking corrective action as soon as a mishap occurs in any part of the launch. 11

However, the risks associated with space disposal increase proportionately with the number of launches. Consequently, a capsule and vehicle of high integrity must be developed. Furthermore, disposal of all high level wastes in space is probably impractical because of the high launch rate required and the resulting environmental impact, energy requirements, and economic factors. Therefore, to reduce the number of required launches, an effective method of partitioning the wastes is needed so that only the longest-lived radioisotopes are disposed of in space.

Another disadvantage to space disposal is the cost, which is estimated to be $\$ 750 / \mathrm{kg}$ (1978 dollars) for the space shuttle launches alone. Other costs would arise from special reprocessing, partitioning, and packaging. ${ }^{6} \mathrm{~A}$ final disadvantage is that even though most mishaps during launch might be corrected, there may be a situation for which no corrective action can be taken.

\subsection{TRANSMUTATION}

Transmutation is a process whereby long-lived fission products are converted to shorter lived nuclides by bombarding the nuclei with either photons or other subatomic particles. This conversion greatly reduces the long-term risk associated with many fission products and shortens the time over which isolation of the wastes must be assured. Spent fuel reprocessing and plutonium recycling are a necessity in order to partition the wastes for transmutation. Transmutation is accomplished by placing partitioned wastes in any device producing subatomic particles (e.g., accelerators, cyclotrons, or reactors). Commercial nuclear power reactors are favored as transmutation devices because of their demonstrated technology and their availability in large enough numbers to handle the materials being recycled. 6

Advantages associated with transmutation include total irreversibility and simplified disposal, since the transmuted wastes need not be isolated for as long as the original fission products. The disadvantage of transmutation lies mainly in the need to develop the technology to perform the process. A practical partitioning process with a very high degree of recovery of acti- 
nides and other long-lived fission products must be developed in addition to an extensive compilation of neutron cross sections for the actinides and fission products. Finally, more research is needed on the reactors and/or accelerators performing transmutation. It is estimated that ten or more years of feasibility studies must be made. 6

\subsection{DISPOSAL BY ROCK MELTING IN DEEP MINED CAVITIES}

This method of waste disposal, like transmutation, is intended for reprocessing wastes: The process involves pumping aqueous solutions or slurries of solidified waste through a hole drilled into a cavity mined in a deep and relatively impermeable geologic formation where the waste would ultimately melt, dissolve, and become an integral part of the formation.

The advantages of this waste technology include the capability of disposing concentrated wastes soon after their generation, the incorporation of the waste into the resolidifed rock upon cooling, the greater disposal depth possible (greater than that of a mined repository), and elimination of transportation through colocation of cavities and reprocessing plants. A major disadvantage is that recovery of the wastes in the event of unforeseen problems is virtually impossible. However, research has been focused on engineering features rather than geologic, rock mechanics, and geohydrologic aspects. Hence, leachability of the waste form, groundwater transport, and mechanical response of the geologic formation to the heat pulse are largely unknown. 6

\subsection{DISPOSAL IN DEEP DRILLED HOLES}

The final waste disposal technology being investigated is the burial of radioisotopes in deep drilled holes. Containers of waste would be emplaced in up to $1.2-\mathrm{km}$ columns at the bottom of holes $8-13 \mathrm{~km}$ deep. The technology used to drill holes to depths in excess of $6 \mathrm{~km}$ with bottom diameters of 15-20 cm has been established already in the oil and natural gas industry. Drilling to depths of $12 \mathrm{~km}$ with bottom diameters of $38 \mathrm{~cm}$ would merely be an extension of current technology at an increased cost.

The advantages of this method are that at such depths, there is little chance of the waste cannisters being exposed to the biosphere as a result of their being disturbed through groundwater transport, human intrusion, or climatic or surface changes. Disadvantages lie in the uncertainties in geologic, geophysical, and geochemical properties of specific sites; unknown effects of temperature, pressure, and thermal stress on the surrounding rock caused by a long column of hot wastes; and questions relating to the retrievability of the wastes. The costs associated with deep hole drilling have been estimated to be $\$ 40 / \mathrm{kg}$ of reprocessed HLW for a 12-km hole. Spent fuel buried in this manner would be 15 times more expensive than reprocessed HLW. 6 


\section{RISKS OF RADIOACTIVE WASTE DISPOSAI}

\subsection{INTRODUCTION}

There are several issues that must be addressed by both the scientific community and government officials regarding the risks of nuclear waste disposal technologies. Some of thes issues are: the kinds of waste a particular technology can accommodate, the isolation potential, the proliferation risk, the land area used, the transportation hazards, and the implications of an accident when the waste technology is in place. For example, space disposal of radioactive waste could afford total isolation once the waste is in space, but the safe tranport of these wastes into space remains a major risk in the use of this technique. Therefore, the purpose of this chapter is to identify possible waste disposal technologies for a glven waste type and to evaluate the risks involved. Each of the proposed waste disposal technologies is evaluated in terms of the aforementioned issues. Table 1 summarizes this discussion along with listing the current status and cost of each technology.

\subsection{RISKS OF HIGH-LEVEL WASTE DISPOSAL}

As noted in Chapter 2, HLWs consist of either spent fuel assemblies or wastes resulting from the reprocessing or recycling of spent fuel and must be isolated from the biosphere for many thousands of years because of the long-lived radioisotopes they contain. Nuclear industry spokesmen claim the disposal of HLW is a major reason for public opposition to nuclear power. Hence, most of the research work on radioactive waste disposal has concentrated on HLW disposal.

Burial in deep geologic formations is the most widely researched solution to the HLW disposal problem. The nation's first waste disposal pilot project, WIPP, which will begin operation in 1985, will be the geologic burial of radioactive wastes. Although favored by the scientific community as a solution to the problem of HLW disposal, the technique faces stiff opposition from the United States Geological Survey (USGS). The USGS questions the stability of rock formations once the $\mathrm{HLW}$ has been emplaced. The effects of mechanical, chemical, and thermal disturbances on the host rock are largely uncertain and may lead to a breach of the waste repusilury. Cuupled with groundwater transport, the wastes could return to the biosphere much sooner than expected and with serious consequences.

Proponents of geologic repositories argue that the risks associated with geologic burial can be lessened through conservarive design and a systems approach. $9^{\circ}$ A systems approach recognizes that the fate of HLW is governed by the chemical and physical properties of the host rock, by the natural geologic environment, and by engineered barriers such as the waste form. Consequently, judicious choice of the host medium, waste form, and back-up systems, multiple natural and engineered barriers should preclude the release of radionuclides to the biosphere. Furthermore, wastes will be buried at depths of 600 meters where the characteristic time intervals required for any substantial change are on the order of millions of years. 
Table 1. Technologies for Waste Disposal and Issues Involved

$$
\text { ..... }
$$

\begin{tabular}{|c|c|c|c|c|c|c|c|c|}
\hline Technology & $\begin{array}{l}\text { Status of } \\
\text { lechnology }\end{array}$ & $\begin{array}{l}\text { Wastes } \\
\text { Technology } \\
\text { Can } \\
\text { Accomnodate }\end{array}$ & Costs & $\begin{array}{l}\text { Isolation } \\
\text { Potential }\end{array}$ & $\begin{array}{l}\text { Proliferation } \\
\quad \text { Risk }\end{array}$ & Land Use & $\begin{array}{l}\text { Transportation } \\
\text { Hlazards }\end{array}$ & $\begin{array}{c}\text { Implications of } \\
\text { Accident }\end{array}$ \\
\hline $\begin{array}{r}\text { Geologic } \\
\text { Burial }\end{array}$ & $\begin{array}{l}\text { Pilot plant (WIPP) } \\
\text { to open in } 1985\end{array}$ & $\begin{array}{l}\text { HLW, TW } \\
\text { wastes, LLW }\end{array}$ & $\begin{array}{l}\$ 50 / \mathrm{kg} \\
\text { (spent fuel) }\end{array}$ & $\begin{array}{l}\text { Moderately High } \\
\text { - depends upon } \\
\text { geologic activity } \\
\text { of site }\end{array}$ & $\begin{array}{l}\text { No reprocessing } \\
\text { requi red }\end{array}$ & $\begin{array}{l}0.5 \mathrm{~km}^{2} \text { could } \\
\text { accomodate an- } \\
\text { nual HLW from } \\
400 \text { 1000-MWe } \\
\text { reactors }\end{array}$ & $\begin{array}{l}\text { Regional centers } \\
\text { minimize trans- } \\
\text { portation }\end{array}$ & $\begin{array}{l}\text { Retrievability } \\
\text { can be built } \\
\text { in }\end{array}$ \\
\hline $\begin{array}{l}\text { Seabed } \\
\text { Disposal }\end{array}$ & $\begin{array}{l}\text { Pilot project in } \\
\text { operation by } 1995\end{array}$ & $\begin{array}{l}\text { HLW, TRW } \\
\text { wastes, LLW }\end{array}$ & Not known & $\begin{array}{l}\text { Moderately High } \\
\text { - depends upon } \\
\text { geologic activity } \\
\text { of site }\end{array}$ & $\begin{array}{l}\text { No reprocessing } \\
\text { requi red }\end{array}$ & No land used & $\begin{array}{l}\text { Travel from in- } \\
\text { land U.S. can be } \\
\text { extensive. Special } \\
\text { port and ship fa- } \\
\text { cilities needed }\end{array}$ & $\begin{array}{l}\text { Not generally } \\
\text { retrievable }\end{array}$ \\
\hline $\begin{array}{l}\text { Space } \\
\quad \text { Di sposat }\end{array}$ & $\begin{array}{l}\text { Feasibility study } \\
\text { due in } 1981 \text { study }\end{array}$ & $\begin{array}{l}\text { Reporcessed } \\
\text { lit.W and TRU } \\
\text { wastes }\end{array}$ & $\begin{array}{l}>\$ 750 / \mathrm{kg} \\
\text { of. waste } \\
\text { in space }\end{array}$ & Very high & $\begin{array}{l}\text { Reprocessing. } \\
\text { required }\end{array}$ & No land used & $\begin{array}{l}\text { Much travel to } \\
\text { launch site-safety } \\
\text { of launches ques- } \\
\text { tioned }\end{array}$ & $\begin{array}{l}\text { Possible to } \\
\text { correct a mis- } \\
\text { hap during } \\
\text { launch }\end{array}$ \\
\hline $\begin{array}{l}\text { Transmutation } \\
\text { (wich geo- } \\
\text { logic } \\
\text { burial) }\end{array}$ & $\begin{array}{l}\text { 3-yr (since 1977) } \\
\text { fessibility study } \\
\text { in progrese. }\end{array}$ & $\begin{array}{l}\text { Reprocessed } \\
\text { HLW and TRU } \\
\text { wastes }\end{array}$ & Nor known & $\begin{array}{l}\text { Very higl, - } \\
\text { transnuced wastes } \\
\text { much less lazard- } \\
\text { ous }\end{array}$ & $\begin{array}{l}\text { Reprocessing } \\
\text { required }\end{array}$ & $\begin{array}{l}\text { Same as geo- } \\
\text { logic burial }\end{array}$ & $\begin{array}{l}\text { Same as geologic } \\
\text { burial }\end{array}$ & $\begin{array}{l}\text { Same as geo- } \\
\text { logic burial }\end{array}$ \\
\hline Rock Melting & $\begin{array}{l}\text { Feasibility being } \\
\text { studied }\end{array}$ & $\begin{array}{l}\text { Reprocessed } \\
\text { HLW and TRU } \\
\text { wastes }\end{array}$ & Not known & $\begin{array}{l}\text { High - depends } \\
\text { upon geologic } \\
\text { activity }\end{array}$ & $\begin{array}{l}\text { Reprocessing } \\
\text { required }\end{array}$ & $\begin{array}{l}\text { Less than } \\
\text { geologic } \\
\text { burial }\end{array}$ & $\begin{array}{l}\text { Same as geologic } \\
\text { burial }\end{array}$ & $\begin{array}{l}\text { Not retriev- } \\
\text { able }\end{array}$ \\
\hline $\begin{array}{l}\text { Deep Drilled } \\
\text { Holes }\end{array}$ & $\begin{array}{l}\text { Conceptual stage } \\
10-15 \text { yrs of } \\
\text { feasibility } \\
\text { studies planned }\end{array}$ & $\begin{array}{l}\text { HLW, TRU } \\
\text { wastes, liquid } \\
\text { LLW }\end{array}$ & $\begin{array}{l}\$ 40 / \mathrm{kg} \text { of } \\
\text { reprocessed } \\
\text { wastes, } \$ 600 / \\
\mathrm{kg} \text { of spent } \\
\text { fuel }\end{array}$ & $\begin{array}{l}\text { High-depends } \\
\text { upon geologic } \\
\text { activity }\end{array}$ & $\begin{array}{l}\text { No reprocess- } \\
\text { ing required }\end{array}$ & $\begin{array}{l}\text { Less than } \\
\text { geologic } \\
\text { burial }\end{array}$ & $\begin{array}{l}\text { Same as geologic } \\
\text { burial }\end{array}$ & $\begin{array}{l}\text { Not generally } \\
\text { retrievable }\end{array}$ \\
\hline $\begin{array}{l}\text { Slabllow Land } \\
\text { Burial }\end{array}$ & In progress. & LLW & . & $\begin{array}{l}\text { Low to moder- } \\
\text { ately high. } \\
\text { Depends upon } \\
\text { engineered and } \\
\text { geologic bar- } \\
\text { riers }\end{array}$ & None & $\begin{array}{l}\text { Trench of } \\
6800 \mathrm{~m}^{3} \\
\text { can accon- } \\
\text { modate } \\
4050 \mathrm{~m}^{3} \text { of } \\
\text { LLW }\end{array}$ & $\begin{array}{l}\text { Sane as geologic } \\
\text { burial }\end{array}$ & $\begin{array}{l}\text { Retrievability } \\
\text { can be built } \\
\text { in }\end{array}$ \\
\hline
\end{tabular}


The land requirements for geologic burial of HLW should not be very substantial. With each waste cannister occupying an area of 100 square meters at a depth of 600 meters, Cohen ${ }^{3}$ has calculated that even an all nuclear U.S. electric-power system (assuming 400, 1,000-megawatt plants), the HLW annually generated would occupy an area of less than half a square kilometer. Concerning transportation issues, regional repositories are advocated so that the wastes will not have to be transported long distances to be disposed of. Retrievability of the waste cannisters once they have been emplaced could afford extra protection against accidents. This feature could be built into a repository at a marginal cost. However, although many generic studies on different rock formations have been made, site-specific data is still needed. After a particular site is chosen, analysis of the site parameters will yield more exact estimates of the isolation potential of the particular site, since models exist that can predict geologic activity given various site parameters.

Beabed disposal is a secund candidate fur dispusal of either spent fuel or reprocessing wastes. It has been recognized that merely placing wastes on the seafloor is ineffective because of the corrosiveness of seawater and the relatively short residence time (i.e., 100-1000 years) of even the deep water. Since the water column cannot be considered a primary barrier to the transport of HLW, attention has been focused upon the adequacy of the sediments as a barrier to the transport of radionuclides to the water column. Investigations are currently under way to determine the feasibility of seabed disposal. Assuming adherence to the current schedule, the program calls for establishment of environmental and technical feasibility by 1983, engineering feasibility by 1990 , and demonstration by as early as 1995.6 A drawback to seabed disposal is that it heightens the transportation risk because of increased overland transport in addition to requiring special port and ship facilities to insure safe handing of the HLW. Overland transport could cause significant difficulties because of the proliferation of local ordinances prohibiting or severly restricting the transport of nuclear wastes through a municipality. 12

Another disposal téchnology that accommodates both spent fuel and reprocessing wastes is disposal in deep drilled holes. Similar problems confronting geologic disposal are common to deep drilled hole burial. But other than conceptualizing possible systems, little has been done to demonstrate technical feasibility, which will require 10-15 years of studies.

The options of rock melting in deep mined cavities, extraterrestrial disposal, and transmutation all entail the risks associated with spent fuel reprocessing, namely, plutonium proliferation. Since the Carter Administration is deferring spent fuel reprocessing indefinitely, these technologies would probably not be implemented before the turn of the century. These technologies are promising and are being investigated as a hedge against any problems that may cause geologic repositories to be inadequate. Transmutation of HLW would most likely be coupled with geologic burial, thereby requiring less stringent isolation requirements because of the reduced hazards of transmuted wastes. A three-year DOE-funded program (begun in 1977) is under way to determine the feasibility of and incentives for transmutation. A safety assessment of extraterrestrial disposal is due to be completed by 1981, while the technology of rock melting in deep mined cavities is still in the early stages of feasibility studies. Table 1 summarizes the critical issues to consider when assessing the potential usefulness of the waste 
disposal technologies proposed for HLW disposal. Ice sheet disposal was not even considered because it has been widely discounted in the technical community. 2,12 This waste option was not even recommended by the Interagency Review Group (IRG), a task force instituted by President Carter to study nuclear fuel cycle waste management, and will most 1 ikely not be implemented.

\subsection{RISKS OF TRANSURANIC (TRU) WASTE D.ISPOSAL}

As noted in Chapter 2, TRU wastes result predominately from spent fuel reprocessing and fabrication of mixed-oxide fuel elements. Hence, the amount generated depends upon the choice of fuel cycle. Although the heat generated from TRU wastes is not nearly as great as HLW, the radioactive danger of TRU wastes is comparable to HLW, i.e., 10 $3-10^{6}$ years. Thus, the technologies for and risks associated with TRU waste disposal are similar to those of HLW disposal. Yet, because TRU wastes generate less heat, repository design restrictions could be relaxed in comparison to HLW repositories, and a TRU-dedicated repository could be operational first. This strategy has been advocated in the IRG report to the President. 1

\subsection{RISKS OF LOW-LEVEL WASTE (LLW) DISPOSAL}

Low-level wastes occur in virtually all phases of the nuclear fuel cycle in addition to being produced in medical, research, and manufacturing activities that utilize radioisotopes. The current method of LLW disposal is by shallow land burial. This type of burial involves placing treated or untreated wastes in trenches and covering the wastes with a meter or more of soil. Sites are selected on the basis of favorable geologic and hydrogeologic characteristics that are likely to isolate the wastes on the site until they have decayed to innocuous levels. The DOE has 14 active and two closed nuclear waste burial grounds, and commercial operators maintain three open and three closed sites. 1 In the past, some LLW was disposed of by dumping containerized wastes overboard at specific ocean sites and letting the wastes settle to the seafloor. This practice was suspended in 1970 .

However, because LLW consists of products with greatly varying levels of radioactivity (half-lives range from a few seconds to a few thousand years), and some LLW burial sites have developed leaks (although no public hazard has occurred), all of the wastes cannot be disposed of by shallow land or seafloor disposal methods. Geologic burial and ocean sediment burial may be employed for certain long-lived wastes. Additionally, liquid LLW could be disposed of by deep well injection. This technique involves pumping liquid wastes several hundred meters into rock formations capable of retaining the wastes until they have decayed to safe levels. Shallow land and seafloor burial could also be made to provide more isolation potential by not relying merely upon geologic barriers but by using engineered barriers such as modifying the waste form and improving the packaging. (See Table 1 for lists of the technologies for and issues involved in LLW disposal.)

Approximately $57,000 \mathrm{~m}^{3}$ of commercial LLWs are disposed of each year at commercial sites. At this rate, sufficient capacity at the three operating commercial sites will. be available only for the next 5-10 years. Due to uncertainties in Federal and State regulatory programs, however, commercial 
operators are unwilling to investigate additional sites. To reverse this trend, a national plan for the management of LLW needs to be implemented. This plan must address various LLW disposal strategies to be pursued as well as site-licensing procedures and EPA standards on packaging of wastes and onsite selection. Time tables for feasibility studies, R\&D activities, and demonstration plants for LLW disposal must be established. Unless a comprehensive LLW program is adopted, industry and government may be left with no place to dispose of such material.

\subsection{RISKS OF URANIUM TAILINGS DISPOSAL}

Possibly the largest quantities of radioactive waste are uranium tailings; 9-14 t are generated annually with $130 \mathrm{t}$ already in existence. 1 The immense volume of these wastes obviously prohibits disposal in geologic repositories or other methods proposed for HLW, TRU waste, or LLW disposal. Yet, because of the hazard they pose, measures must be taken to minimize the risks posed by the exposed piles scattered at both active and inactive uranium milling sites. As an interim measure at active mill sites, the NRC is requiring the mill operators to dispose of mill tailings in such a way that radon emission is reduced to about twice the natural background rate. This requirement is being accomplished by covering the tailings with clay and soil and regrading to resist wind and water erosion. Underground burial of tailings is being proposed as a method of future disposal. Tailings may be returned to the mine pits from which they came or placed in specially excavated below-grade pits. To effect more permanent regulation of active mill sites, the NRC is preparing a Generic Environmental Impact Statement (GEIS) on uranium mill tailings. The cleanup of inactive sites is the responsibility of the DOE. Legislation is being considered by Congress to authorize the necessary actions.

\subsection{RISKS OF DECONTAMINATION/DECOMMISSIONING (D/D) WASTE DISPOSAL}

Decommissioning of nuclear facilities will also result in a large amount of wastes. However, the waste generated from dismantlement can be characterized according to waste type, i.e., HLW, TRU waste, or LLW, and disposed of accordingly. The site itself must be cleaned up sufficiently to provide unrestricted use of the land. Otherwise, long-term institutional control must be provided. Since $D / D$ waste is a newcomer to the nuclear waste disposal forum, standards still need to be developed specifying techniques and procedures to accomplish $\mathrm{D} / \mathrm{D}$. 


\section{CONCLUSIONS}

Several conclusions can be made based upon this study of the wastes generated by the nuclear fuel cycle and the technologies for and risks involved with radioactive waste disposal. First, it must be realized that regardless of future nuclear policy, a nuclear waste disposal problem does exist and must be dealt with. Even a moratorium on new nuclear plants leaves us with the wastes already in existence and wastes yet to be generated by reactors in operation. Thus, at the very least, technologies to effectively dispose of our current waste problem must be researched and identified and, then, based upon the findings, facilities to dispose of the radioactive wastes must be built.

Second, the magnitude of the waste disposal problem is a function of future nuclear policy. As noted in $\mathrm{Table} 1$ there are some waste disposal technologies that are suitable for both forms of HLW (spent fuel and reprocessing wastes), whereas others $c$ an be used with only reprocessed wastes. Therefore, the sooner a decision on the future of nuclear power is made the more accurately the magnitude of the waste problem will be known, thereby identifying those technologies that deserve more attention and funding and those that $c$ an be abandoned. This determination will help to focus the research and development effort so that we can better solve the radioactive waste disposal problem.

Finally, the results in Table 1 show that there are risks associated with every disposal technology. One technology may afford a higher isolation potential at the expense of increased transportation risks in comparison to a second technology. Establishing the types of risks we are willing to live with must be resolved before any waste disposal technology can be instituted for widespread commercial use. 


\section{REFERENCES}

1. The Interagency Review Group on Nuclear Waste Management, Report to the President by the Interagency Review Group on Nuclear Waste Management, TID-29442 (March 1979).

2. The Nuclear Energy Policy Study Group, Nuclear Power: Issues and Choices, Ballinger, Cambridge, pp. 243-267 (1977).

3. Cohen, Bernard L., The Disposal of Radioactive Wastes from Fission Reactors, Scientific American, 236(6):21-31 (June 1977).

4. U.S. Department of Energy, Directorate of Energy.Research, Report of Task Force for Review of Nuclear Waste Management, DRAFT, DOE/ER-0004/D. (February 1978).

5. Blomeke, J.O. and C.W. Kee, Projections of Wastes to be Generated, in Proceedings of the International Symposium on the Management of Wastes from the LWR Fuel Cycle, Denver, Colo. July 11-16, 1976: U.S. Energy Research and Development Adm. Report, CONF-76-0701, p. 96-117 (1976).

6. The Interagency Review Group on Nuclear Waste Management, Subgroup Report on Alternative Technology Strategies for the Isolation of Nuclear Waste, DRAFT, TID-28818 (October 1978).

7. APS Study Group on Nuclear Fuel Cycles and Waste Management, Rev. Mod. Phys., 50(1)Part II:5107-5142 (January 1978).

8. Carter, Luther J., Uranium Mizl Tailings: Congress Addresses a LongNeglected Problem, Science, 202(4364):191-195 (1978).

9. Nuclear Waste Management: Looking for the Cure, EPRI Journal, 3(6):41-42 ( July/August 1972).

10. Millar, C.H., in Proceedings of an International Symposium on Management of Wastes from the LWR Fuel Cycle, Denver, Colorado, J.A. Powell, Ed., ERDA, Washington, D.C. (1976).

11. Burns, R.E., W.E. Causey, W.E. Galloway, R.W. Nelson, Nuclear Waste Disposal in Space, NASA Technical Paper 1225 (May 1978).

12. Cordaro, Matthew C., Federal Regulation of Spent Fuel Transportation -Surrender or Indecision, paper presented before Atomic Industrial Forum, Inc., Fuel Cycle Conference '79, Atlanta (March 14, 1979). 